\title{
Exploring the Linkages between Poverty, Marine Protected Area Management, and the Use of Destructive Fishing Gear in Tanzania
}

\author{
Patricia Silva
}

\begin{abstract}
Coastal resources in Tanzania have come under increasing pressure over the past three decades, which has led to a significant decline in the biodiversity and productivity of coastal ecosystems. The livelihoods of coastal communities that directly depend on these resources are consequently under increasing threat and vulnerability. Marine Protected Areas (MPAs) are one tool for managing coastal and marine resources that have been increasingly used in Tanzania. Promotion of alternative income generating activities (AIGA) is often a component of MPA management strategies to reduce fishing pressure and address poverty concerns. However, empirical evidence on whether these AIGA are successful in reducing pressure on fisheries, or their impact on poverty, is scarce and inconclusive. This paper seeks to contribute to this debate by investigating the linkages between household characteristics, MPA activities, and household choice of fishing gear. The empirical analysis is based on household survey data from a sample of villages located along the coast of mainland Tanzania and Zanzibar. We find that some aspects of poverty increase the likelihood of using destructive fishing gear. MPAs do not directly affect household choice of fishing gear. However, households participating in AIGA are less likely to use destructive fishing gear, suggesting that MPA support to these activities in Tanzania has a positive influence on household choice of fishing gear. We also find the use of destructive fishing gear is associated with higher consumption levels, whereas participation in AIGA does not significantly affect household consumption levels.
\end{abstract}

\section{Acknowledgements}

We are grateful to the Trust Fund for Environmentally and Socially Sustainable Development for generous financial support. Thanks to Sushenjit Bandyopadhyay, Robert Deacon, Paavo Eliste, Kirk Hamilton, Indumathie Hewawasam, Sergio Margulis, and Jack Ruitenbeek, for useful discussion and valuable comments provided. We also thank the participants of the workshop on Marine and Coastal Conservation and Management, held in Dar es Salaam on June 27, 2005, for the many insightful comments and suggestions.

\section{World Bank Policy Research Working Paper 3831, February 2006}

The Policy Research Working Paper Series disseminates the findings of work in progress to encourage the exchange of ideas about development issues. An objective of the series is to get the findings out quickly, even if the presentations are less than fully polished. The papers carry the names of the authors and should be cited accordingly. The findings, interpretations, and conclusions expressed in this paper are entirely those of the authors. They do not necessarily represent the view of the World Bank, its Executive Directors, or the countries they represent. Policy Research Working Papers are available online at http:/lecon.worldbank.org. 


\section{Introduction}

Coastal resources in Tanzania have come under increasing pressure over the past three decades, which has led to a significant decline in the biodiversity and productivity of marine fisheries. The Tanzania State of the Coast report (2003) concludes that the inshore fisheries of mainland Tanzania and Zanzibar are over exploited and that shallow reefs are degraded. In a comprehensive review of fisheries studies in Tanzania, Jiddawi and Ohman (2002) report that the average size of lobsters and octopus has decreased substantially and the most abundant sea cucumber species are the low valued species due to overexploitation of these resources. Other investigations, such as interviews with older fishermen, confirm the trend in the decline of fisheries resources in coastal areas (MANREC, 2005).

The coastal areas of mainland Tanzania are home to approximately 25 percent of the country's population (about 8 million people), and approximately 1 million people live in the islands of Zanzibar. Most of the coastal population depend on these coastal resourcesparticularly fisheries - for food and income generation. The poor tend to be the most dependent on these resources and are therefore the most severely affected when the coastal environment is degraded or their access to these resources is limited.

Marine Protected Areas (MPAs) are one tool for managing coastal and marine resources that have been increasingly used in Tanzania and elsewhere. ${ }^{1}$ This has followed growing consensus among scientists and fisheries managers that conventional measures, such as taxes, quotas, season length and gear restriction management, have failed to prevent depletion of fishery stocks and a new approach is needed (Smith and Wilen, 2003; Pezzey and others, 2000). Conventional fishery management measures have proved particularly difficult to implement in reef fisheries, due to the diversity of species exploited and few resources available for enforcement in developing nations where many of the reefs are located. MPAs have been proposed as a promising alternative for fisheries management, partly because they are perceived as a simpler mechanism to enforce and data requirements for effective management are lower (Pezzey and others, 2000). Interest in MPAs has also been sparked by growing concern about the environmental damages of fishing and desire to preserve areas in

\footnotetext{
${ }^{1}$ We use the term MPA broadly to include any marine managed area, such as marine parks, reserves, sanctuaries, conservation areas, as well as collaborative management arrangements.
} 
as pristine as possible state (Hannesson, 2002). Endorsement by a leading group of marine scientists of MPAs as an effective management tool to help protect and restore fisheries, and conserve biodiversity, by protecting some or all resources in specific areas from extractive use, further spurred the establishment of MPAs around the world (Scientific Consensus, 2001).

In mainland Tanzania, concerns with the growing threats to coastal and marine resources and degradation of coastal habitats led to the establishment of the Marine Reserves Park Unit (MRPU) in 1994, under the Ministry of Natural Resources and Tourism (MNRT). MRPU has the mandate to establish and ensure sustainable conservation of areas of outstanding marine ecological importance and manage them in partnership with coastal communities on mainland Tanzania. Protected areas in Zanzibar are under different legal frameworks and institutions. ${ }^{2}$ However, the purpose of the protected areas in Zanzibar, as stated in the Environment Act, are also to promote sustainable utilization of resources by those living in or near protected areas, as well as manage and protect biological diversity. The establishment of a Marine Conservation Unit (MCU), within the Department of Fisheries, to oversee and manage MPAs in Zanzibar is soon to become effective.

Whether MPAs can simultaneously achieve the objectives of conservation and sustaining fishery catches has become a topic of considerable debate in the scientific and economic literature (Hilborn and others, 2004; Botsford, 2005; Hastings and Botsford, 2003; Carter, 2003; Smith and Wilen, 2003). Proposals calling for protection of 20 to 30 percent of oceans have led one to question whether such large scale implementation of MPAs can provide both conservation and fisheries benefits and what are the trade offs between these objectives (Hilborn and others, 2004). The theory and models developed to examine the impact of MPA design on achieving conservation and fisheries benefits are still in their infancy (Botsford and others, 2003). Recognizing that MPAs are tools to specify the location of fishing, and that they do not affect the incentives or replace institutional structures needed to address over-fishing, suggests a more conservative approach be taken to promote MPAs as mechanisms to improve fishery yields (Hilborn and others, 2004).

\footnotetext{
${ }^{2}$ Environmental issues, including wildlife and fisheries management, are governed by autonomous institutional and legal structures in mainland Tanzania and Zanzibar. Both have considerable legislation and institutional experience with protected areas management, with similar overall objectives, but different means of implementation (Ruitenbeek and others, 2005).
} 
In the context of developing countries, there is widespread concern that if the MPAs established do not benefit coastal communities, increased degradation and a decrease in the services provided by the existing coastal ecosystems may ultimately occur, leading to greater poverty. Hence, conservation organizations supporting MPAs in Tanzania, such as WWF and IUCN, are trying to address poverty in their conservation programs (Ireland, 2004). IUCN (2003) states that "it is unacceptable to carry out conservation activities in areas of high or endemic poverty while turning a blind eye to the needs of the poor people who live there and depend on the same biological resources that are often those that we wish to conserve." There is also growing recognition that conservation is unlikely to be effective if users of resources are excluded from the decision making process (Ireland, 2004). However, some have argued that when conservation programs have become too diluted by strategies to promote community development and greater local participation in decision making, conservation objectives may suffer (Kramer and others, 1997; Brandon and others, 1998, Oates, 1999). How to balance the MPA multiple objectives of conservation and development is therefore a topic of increasing relevance for countries such as Tanzania.

This paper seeks to contribute to this literature by investigating the linkages between household characteristics, MPA management activities, and household choice of fishing gear. We first look at which household characteristics determine the use of destructive fishing gear. In particular, are poor households more likely to use destructive fishing gear? And does the use of destructive fishing gear increase household welfare? Second, we seek to evaluate the impact of MPAs on the use of destructive fishing gear and household welfare. Do MPAs in Tanzania, through their efforts in enforcement of fishing gear regulations, education and awareness campaigns on the impacts of destructive fishing gear, fishing gear exchange programs, and provision of alternative income generating activities (AIGA), have an influence on household use of destructive fishing gear? Do MPA restrictions on access negatively impact households dependent on fishing? These are the questions this paper seeks to answer.

The empirical analysis is based on purposely collected household survey data from a sample of villages located along the coastal areas of mainland Tanzania and Zanzibar. ${ }^{3}$

\footnotetext{
${ }^{3}$ Fishing is not longer included as a separate economic activity in national population censuses and surveys. Although some data on the number of fishers is collected and published by the MNRT in their annual statistics,
} 
Detailed information on the different types of fishing gear used by households was specifically collected in order to better understand the patterns of usage of different fishing gear and whether MPAs have an impact on these decisions. Tanzania has committed itself to increasing the percentage of its coastal and marine areas under MPAs to 10 percent by 2012 and 20 percent by 2025 (Ruitenbeek and others, 2005). Knowledge of whether MPAs can effectively reduce fishing pressure by affecting the use of destructive fishing gear and how MPA activities impact the poor is essential to inform policy decisions to ensure coastal and marine resources are managed in a sustainable, effective, and equitable manner. We find that MPAs reduce the likelihood of households targeting near shore fish species and using destructive fishing gear. However, the latter impact is indirect and limited to influencing the choice of fishing gear of households participating in AIGA established by the MPA. We also find the use of destructive fishing gear is associated with higher consumption levels, whereas participation in AIGA does not significantly affect household consumption levels.

The paper is structured as follows. Section 2 provides an overview of fishing in coastal communities in Tanzania and the policies pursued in Tanzania to address problems in this sector. Section 3 describes the dataset used for the analysis, focusing on the characteristics of coastal fishing communities. Section 4 introduces the empirical strategy employed for the analysis, including the underlying theoretical framework and econometric specification adopted. Section 5 presents the results of the econometric analysis and section 6 concludes with a discussion of the policy implications.

\section{Fishing and the role of MPAs in Tanzania}

Tanzania's coastline runs approximately north-south and is dominated by three large offshore island-Pemba, Zanzibar, and Mafia Island. There are also other small islands, such as Misali Island, west of Pemba, and Mnemba and Chumbe islands, off Zanzibar. There are fringing and patch reefs along much of the mainland coast and these islands (Leon and others, 2004). Tanzania's continental shelf covers an estimated $17,900 \mathrm{~km}^{2}$, with waters up to 200 meters in depth. It is generally narrow-typically extending about $4 \mathrm{~km}$ offshore-except at

this survey with demographic data and detailed fishing gear usage data provides a unique opportunity for a detailed analysis. 
the Zanzibar and Mafia channel, where the shelf extends to some 60 to $80 \mathrm{~km}$ (Ruitenbeek and others, 2005). Along most of Tanzania's coast line, fishing is an open access activity in which anyone can participate. ${ }^{4}$

Most marine fishing activity takes place in the shallow near shore waters, using traditional vessels and gear. Table 1 provides an overview of the different types of fishing gear commonly used by artisanal fishermen in Tanzania. About 95 percent of the total marine catch is estimated to come from this type of small scale artisanal fishery (Jiddawi and Ohman, 2002). Fishing is an attractive activity for the poor in particular, as it does not necessarily require the ownership of any assets and has very low start up costs. It also generates food and cash income on a daily basis. While most fishing households in coastal areas are also engaged to some extent in agriculture, there is less dependence on agriculture on the coast due to the lack of suitable soils for farming which is characteristic of certain areas where coral rag soils dominate the terrain. Fishing also provides some insurance for the poor as a fallback source of food and income in between crops or bad crop years, and during times of economic crisis and instability. Fishing is therefore a crucial activity for the livelihoods of many poor rural households along the coast of Tanzania.

The number of fishermen in the coastal areas of Tanzania has increased over time, although reliable time series statistics are difficult to obtain due to the engagement of many part time fishermen and fluctuations due to changing economic conditions (FAO, 2000). Many fishermen in Tanzania attribute the increasing number of fishermen as one of the major causes of declines in fish catches (MANREC, 2005; Leon and others, 2004). They also cite the lack of vessels and gear to fish offshore as reasons for over exploitation of near shore reef fisheries. The lack of fishing gear, many fishermen say, also leads them to resort to cheap but destructive fishing practices (Leon and others, 2004). Many illegal fishing methods, such as dynamite or poison fishing, spear gun fishing, beach seine nets, drag nets, and gill nets with small mash sizes, are still used due to inadequate enforcement of existing fishing regulations.

\footnotetext{
${ }^{4}$ As of 2002, only 12 industrial vessels were licensed to fish in Tanzania's Exclusive Economic Zone (EEZ), although additional vessels were known to fish in the EEZ illegal. Improved efforts to regulate EEZ fisheries, through monitoring, control and surveillance activities, have yielded valuable information on the potential value of fishery resources in the EEZ.
} 
Table 1. Types of fishing gear used by artisanal fishermen in Tanzania

\begin{tabular}{|c|c|c|}
\hline Type of Gear & Associated Gears & Comments \\
\hline $\begin{array}{l}\text { Gillnets } \\
\text { (Jarife) }\end{array}$ & $\begin{array}{l}\text { Drift gillnet, demersal } \\
\text { gillnet, shark nets }\end{array}$ & $\begin{array}{l}\text { Used in tidal, sub-tidal, and reef areas to capture fish moving with the tides. Target species are tuna, } \\
\text { billfish, kingfish, and sharks. Have high incidental capture of turtles and dolphins. }\end{array}$ \\
\hline $\begin{array}{l}\text { Seine nets } \\
\text { (Nyavu) }\end{array}$ & $\begin{array}{l}\text { Purse seine, ring net, } \\
\text { beach/boat seine }\end{array}$ & $\begin{array}{l}\text { Use light to attract pelagic fish on moonless nights. They are usually dragged onto the beach. Beach } \\
\text { seine is illegal in Zanzibar and only permitted in uninhabited islets. }\end{array}$ \\
\hline $\begin{array}{l}\text { Drag nets } \\
\text { (Kavogo Kigumi) }\end{array}$ & $\begin{array}{l}\text { Any seine net can be used as } \\
\text { a drag net }\end{array}$ & $\begin{array}{l}\text { This method is illegal. Nets may be assisted by divers to untangle, chase, and retain fish. Nets are set } \\
\text { from a boat or from the beach. May use two vessels, and run nets on the bottom. }\end{array}$ \\
\hline $\begin{array}{l}\text { Cast nets } \\
\text { (Kimia) }\end{array}$ & & $\begin{array}{l}\text { Used in sheltered areas. A circular net that is thrown over a shoal of fish or allowed to sink to the } \\
\text { bottom. Closed when retrieved. Caches small fish such as eels, catfish, mullet, silver biddy, and shrimps. }\end{array}$ \\
\hline $\begin{array}{l}\text { Scoop nets } \\
(\text { Senga) }\end{array}$ & & $\begin{array}{l}\text { Used in catching small pelagic fish in the light attracting fishery. Mean catch rate is } 60 \mathrm{~kg} \text { per boat per } \\
\text { day. }\end{array}$ \\
\hline Basket traps & $\begin{array}{l}\text { Dema (large basket), towe } \\
\text { (small basket) }\end{array}$ & $\begin{array}{l}\text { Hexagonal in shape with a single opening. Traps are usually set in seagrass beds, among wild or cultured } \\
\text { seaweed, or coral reefs. The dema mean catch rate is } 1-2 \mathrm{~kg} \text { per trap. }\end{array}$ \\
\hline Fixed traps & Weir, fence, uzio, wando & $\begin{array}{l}\text { Usually made of mangrove stick or palm frond midrib. They are semi-permanent stake tropes that are set } \\
\text { in intertidal areas especially in sheltered areas. Catch rate varies from } 12-100 \mathrm{~kg} \text { per trap. }\end{array}$ \\
\hline $\begin{array}{l}\text { Handline } \\
\text { (Mshipi) }\end{array}$ & & $\begin{array}{l}\text { Probably found on every fishing vessel. Can be used from a vessel or from shore. Currently important as } \\
\text { a sport fishery in the tourist industry at several fishing sites. }\end{array}$ \\
\hline $\begin{array}{l}\text { Longlines } \\
\text { (Dhulumati) }\end{array}$ & $\begin{array}{l}\text { Surface long line, bottom } \\
\text { long line }\end{array}$ & $\begin{array}{l}\text { Mostly for catching tuna especially by industrial vessels in offshore waters. Used by artisanal fishermen } \\
\text { for catching demersal fish. }\end{array}$ \\
\hline $\begin{array}{l}\text { Troll lines } \\
\text { (Kurambaza) }\end{array}$ & & $\begin{array}{l}\text { Lines are usually tailed by a vessel near the surface or at certain depth and use natural or artificial lures } \\
\text { to target specific species, such as tuna and mackarel. }\end{array}$ \\
\hline $\begin{array}{l}\text { Spear, stick } \\
\text { (Mkuki, kijiti) }\end{array}$ & Used for octopus fishing & $\begin{array}{l}\text { A spear is made up of a stick with a sharp end or a piece of iron is inserted at the tip. Kijiti is a stick. } \\
\text { Collection is done by diving or on exposed reefs. Catch rate of } 4-7 \mathrm{~kg} / \text { person/day. }\end{array}$ \\
\hline $\begin{array}{l}\text { Harpoons } \\
\text { (Bunduki, mshare) }\end{array}$ & $\begin{array}{l}\text { Spear gun, used by skin or } \\
\text { scuba divers }\end{array}$ & $\begin{array}{l}\text { Illegal fishing technique which is banned in Tanzania, but still in use. Used for catching lobster and reef } \\
\text { fish. }\end{array}$ \\
\hline $\begin{array}{l}\text { Poison fishing, } \\
\text { dynamite fishing }\end{array}$ & & $\begin{array}{l}\text { These practices are illegal and have been banned because they not only kill target fish, but also other } \\
\text { fish, shellfish, and coral in the area. These methods are particularly harmful to larvae and juvenile } \\
\text { organisms. }\end{array}$ \\
\hline
\end{tabular}

Source: Adapted from Jiddawi and Ohman (2002) 


\section{MPAs in Tanzania}

As of mid-2004, mainland Tanzania and Zanzibar included $1,380 \mathrm{~km}^{2}$ of MPAs and other marine managed areas, amounting to just fewer than 4 percent of the country's territorial seas. Tanzania is committed to increase the percentage of its coastal and marine areas under protection to 10 percent by 2012 and 20 percent by 2025 (Ruitenbeek and others, 2005). Table 2 provides an overview of the different MPAs in mainland Tanzania and Zanzibar. Table 2 shows that Tanzania has adopted a variety of management models as its experience with management of marine resources grows. MPAs, broadly defined as the term is in the context of Tanzania, are emerging as the key mechanism for conservation of the marine environment and management of resource use in Tanzania. Increasing, the vision of the MPRU has turned to promoting "collaborative management and cooperation of user communities, local government authority, NGOs, and private sector agencies to contribute and share the responsibility in the management of protected areas" (Rumisha, 2005).

Under this approach, a collaborative fisheries management area, such as the one recently established in Bagamoyo, is also considered an MPA. Through the establishment of collaborative fisheries management areas, communities are given a role in protecting and establishing rules for use of natural resources in specified areas. The areas to be managed are being selected by villages after a participatory ecological assessment of coral reef sites, which involved local fishermen, district fisheries officers, as well as the private sector participants, such as hotel owners. Mapping of the reefs earmarked for closure by villages participating in the collaborative fisheries management area is being undertaken to provide village fishermen with guidance during their fishing expeditions (TCMP, 2005). The management activities, which include enforcement of gear restrictions and patrolling of closed fishing areas, is supported through the enactment of village and district by-laws. Joint patrols by village environmental committees and district fisheries are officers are then carried out on a regular basis. In the past, even the Navy has been involved in patrolling efforts in the Tanga district, which led to a substantial decline in destructive fishing practices in the area (Makoloweka and Kalombo, 2005).

The extent of community participation in the development of fishing regulations within a managed or protected area and in the enforcement of these regulations varies between different MPAs, but even more formal MPAs (such as the Mafia Island Marine Park) in Tanzania are 
moving towards a more participatory and adaptive management approach, as described above. It is believed that community participation, through input in the development of fishing regulations and joint patrol operations, enhances compliance with such rules and reduces enforcement costs (Makoloweka and Kalombo, 2005).

In this paper we focus on the use of destructive fishing gear, which has been identified as one of the most critical issues facing MPAs in Tanzania (Kazimoto, 2005; Makoloweka and Kalombo, 2005; Rumisha, 2005). This is the case even in areas such as Tanga and Mafia, where efforts to address the use of destructive fishing gear has been taking place for a decade. The Mafia Island Marine Park, for example, has implemented a fishing gear exchange program which has phased out 4 out of 18 seine net fishing groups and provided loans to 6 other fishing groups to facilitate the exchange of more sustainable fishing gear. The Mafia Island Marine Park has facilitated the formation of village enforcement units, training and providing equipment to such units, which carried 191 patrols in 2003. The Mafia Island Marine Park police and fisheries authorities apprehend 27 fishers without licenses or who are fishing in prohibited zones of the park, and confiscated illegal fishing gear in 5 instances in 2003 (Kazimoto, 2005). However, apprehended fishers are not always prosecuted in the legal courts or forced to pay the established fines. There have also been instances of reprisals against marine park police and community members who report illegal fishing activities to authorities.

MPAs in Tanzania have also being engaged in a number of other activities to address the threats of over exploitation and destructive fishing practices, in addition to monitoring and patrolling of illegal fishing activity. Some MPAs in Tanzania have sought to reduce pressure on inshore fisheries by promoting offshore fishing. These MPAs promote deep sea line fishing with lights and use of fish aggregating devices. Promotion of alternative income generating activities (AIGA) is also an integral component of MPA management strategies to reduce fishing pressure and address poverty concerns. The idea driving the promotion of AIGA is to create an incentive for resource users to stop unsustainable resource dependent income generating activities and move into other activities which are non-resource based or at least exploit resources on a more sustainable basis. For this strategy to work, AIGA must be more economically profitable than unsustainable practices. However, profitability is not the only factor. An extensive review of alternative livelihood strategies for coastal communities in the Western Indian Ocean, also points 
to the importance of factors such as attitudes toward risk, access to assets, vulnerability, and institutional influences, in determining household livelihood strategies (Ireland, 2004).

Case study evidence exists from specific project experience showing that new sources of employment and income can be created as a result of efforts to promote these AIGA (Ireland, 2004). Tanzania indeed has already had some successful experience with the introduction of AIGA in coastal areas. Activities such as handicrafts, beekeeping, and seaweed farming at the MIMP generate income of about US\$10 per day for participating members (Ruitenbeek and others, 2005). Programs in Tanga have promoted organic vegetable gardening to fulfill the untapped high demand for vegetables in local markets. While so far the number of households involved in this vegetable growing pilot is small and the amount of income generated not enough to completely disengage households from fishing activities, the potential for profitable scaling up is significant given market demand for vegetables in the area (Ireland, 2004).

However, the empirical evidence on whether or not these AIGA, and other MPAs activities generally, are successful in reducing pressure on fisheries is scarce and shows mixed impacts. A comparative study of costal resource management in the Pacific islands found that most AIGA have not been successful in reducing pressure on coastal resources (World Bank, 1999). By contrast, an analysis of MPAs in the Philippines shows that integrating conservation with promotion of livelihood opportunities is a significant factor explaining MPA's success (Pollnac and others, 2001). As Tanzania embarks in its commitments to expand protection of coastal and marine environment through the use of MPAs, it is important to assess the impact of existing MPAs. This paper seeks to fill the knowledge gap on the determinants of destructive fishing gear use and what impact, if any, MPAs have had on the use of destructive fishing gear. 
Table 2: Characteristics of marine protected areas in Tanzania

\begin{tabular}{|c|c|c|c|}
\hline Marine Protected Area & $\begin{array}{l}\text { Sub-Tidal } \\
\text { Area }\left(\mathrm{km}^{2}\right)\end{array}$ & $\begin{array}{c}\text { Date } \\
\text { established* }\end{array}$ & Comments \\
\hline \multicolumn{4}{|l|}{ Mainland Tanzania } \\
\hline Dar es Salaam Marine & 26.0 & 1975 & Comprises of 4 islands, designated as Marine \\
\hline Reserves System & & & $\begin{array}{l}\text { Reserves in } 1975 \text {, and placed under the mandate of } \\
\text { MPRU in } 1998 \text {. }\end{array}$ \\
\hline Mafia Island Marine Park & 615 & 1995 & $\begin{array}{l}\text { Multiple use marine park with zoning } \\
\left(822 \mathrm{~km}^{2} \text { total area). }\right.\end{array}$ \\
\hline $\begin{array}{l}\text { Tanga Collaborative } \\
\text { Fisheries Management Area }\end{array}$ & 26.4 & $1996-2000$ & $\begin{array}{l}\text { Covers coastal areas of three districts. Set up as } \\
\text { joint initiatives between local communities and } \\
\text { districts and includes closed reefs and the Maziwe } \\
\text { Island Marine Reserve (est. } 1981,2.6 \mathrm{~km}^{2} \text { ). Total } \\
\text { area under management is about } 1,603 \mathrm{~km}^{2} \text {, of } \\
\text { which } 29 \mathrm{~km}^{2} \text { is no-take. }\end{array}$ \\
\hline $\begin{array}{l}\text { Mnazi Bay-Ruvuma } \\
\text { Estuary Marine Park }\end{array}$ & 200 & 2000 & Total area under management is $650 \mathrm{~km}^{2}$. \\
\hline $\begin{array}{l}\text { Bagamoyo Collaborative } \\
\text { Fisheries Management Area }\end{array}$ & tbd & 2005 & $\begin{array}{l}\text { Initiated in } 2004 \text { in Bagamoyo district, seven } \\
\text { villages have established a collaborative fisheries } \\
\text { management area and are in the process of making } \\
\text { final decisions on sites which will be under } \\
\text { community management. }\end{array}$ \\
\hline \multicolumn{4}{|l|}{ Zanzibar } \\
\hline $\begin{array}{l}\text { Chumbe Island Coral } \\
\text { Sanctuary }\end{array}$ & 0.3 & 1994 & $\begin{array}{l}\text { Management delegated to a private company. All } \\
\text { no-take. }\end{array}$ \\
\hline $\begin{array}{l}\text { Menai Bay Conservation } \\
\text { Area }\end{array}$ & 470 & 1997 & A community-managed MPA. \\
\hline $\begin{array}{l}\text { Misali Island Marine } \\
\text { Conservation Area }\end{array}$ & 21.6 & 1998 & $\begin{array}{l}\text { An NGO and community-managed MPA, total area } \\
\text { of } 23 \mathrm{~km}^{2} \text { includes terrestrial; } 1.4 \mathrm{~km}^{2} \text { is no-take } \\
\text { zone. }\end{array}$ \\
\hline $\begin{array}{l}\text { Mnemba Island Marine } \\
\text { Conservation Area }\end{array}$ & 0.15 & 2002 & $\begin{array}{l}\text { Currently all a no-take zone, privately managed } \\
\text { MPA by the Conservation Corporation Africa. }\end{array}$ \\
\hline Ngezi Forest Reserve & 14.4 & 1959 & $\begin{array}{l}\text { Proposed for re-designation as a Nature Reserve; } \\
\text { includes mangroves and beach area. }\end{array}$ \\
\hline $\begin{array}{l}\text { Jozani Chwaka Bay } \\
\text { Conservation Area }\end{array}$ & & 2004 & $\begin{array}{l}\text { A pilot ICM site and protected forest area, } \\
\text { Zanzibar's first national park. }\end{array}$ \\
\hline
\end{tabular}

\footnotetext{
Notes:

* The Date Established normally shows the date that the sub-tidal area was included; some sites that include land were designated as terrestrial protected areas earlier.

${ }^{* *}$ Mnemba Island Marine Conservation Area is to expand beyond the current no-take zone to include wider area under management. It will extend from Nungwi (north of Unguja) to Chwaka Bay, through Mnemba, Kiwengwa, Marumbi, Charawe, Michamvi and Ukongoroni
}

Source: Adapted from Ruitenbeek and others, (2005) 


\section{The Data}

We examine the linkages between poverty, MPA activities, and household choice of fishing gear using household survey data collected at six sites along the coast of mainland Tanzania and Zanzibar: five with existing MPAs (Tanga, Mafia Island, Menai Bay, JozaniChwaka Bay, and Misali Island) and one where a new MPA has been proposed (Kilwa). Each site has ecologically important and diverse marine and coastal habitats which coastal communities depend on for their livelihoods, including coral reefs, mangrove forests, and seagrass beds. Four of the MPAs are legally designated protected areas and one MPA is protected by community based management and locally approved resource management plans. These MPAs were established to protect resources and halt resource overexploitation and destructive fishing practices and all are involved in a number of management actions such as community-based planning, environmental monitoring, enforcement of fisheries regulations, and coral and mangrove conservation activities. These MPAs are also involved in various community development activities such as environmental education, alternative livelihood development, ecotourism, micro loans, and receive external financial and technical assistance. ${ }^{5}$

Four villages in each site of the six study sites were selected in consultation with local and national level authorities, and MPA project staff. Criteria in the selection of villages included the proximity to the protected area, community involvement in conservation, and importance of coastal and marine resources. One village outside the MPA was selected at each site for comparison purposes. A total of 749 households were surveyed in 24 villages. Random sampling at the village level was used to pick households for the survey, to ensure a diversity of households in the sample and avoid systematic bias.

The primary instruments for data collection were household and focus group surveys. Both surveys were developed following a review of guidelines on socioeconomic assessment of MPAs and coral reef management. Prior to the field work, the survey questionnaires were tested to improve or eliminate questions that were confusing or difficult for respondents to answer. The household questionnaires covered information on: household composition and characteristics, economic activities, physical assets, expenditures, food security, education and health, markets, credits and savings, social capital, knowledge and participation in MPA activities, and

\footnotetext{
${ }^{5}$ Technical and management assistance includes: IUCN in Tanga Region, WWF on Mafia Island and Menai Bay, and CARE Tanzania in Jozani-Chwaka Bay and on Pemba Island.
} 
perceptions of change due to MPAs. The survey also collected detailed information on the different types of fishing gear used by households. A more detailed discussion of the fishing related information collected through this survey is presented next.

\section{Coastal community characteristics}

Most coastal communities are relatively isolated and lack access to infrastructure - roads, communications, electricity, and other services. For these communities, fishing is an important economic activity — for both subsistence and income generation purposes. Fishing is the primary occupation and source of income for 32 percent of households in our sample, second to farming, which comprises of 40 percent of households. Households employed in the government, private sector, or other organizations constitute about 10 percent of our sample. Households involved in trading or other self-employment activities account for 6 percent of the sample households interviewed, and other or not employed households make up 11 percent of our sample. However, some households not declaring fishing as their main occupation may be involved in fishing on a part time basis. Indeed 56 percent of households report participating in fishing to some extent.

As Table 3 shows, fishing households in coastal Tanzania harvest a variety of marine species, which include reef, sandy-bottom, estuarine, and pelagic fish, as well as crustaceans (lobsters and crabs), mollusks (oysters and other shellfish), and sea cucumbers. The coral reef fishes are the most abundantly harvested resource because they are easily accessible to the traditional fishermen, which fish in the near shore coastal waters using a dugout or outrigger canoe. Other important species for the poor are the octopus, sea cucumbers, squid, crabs, and other estuarine and mangrove organisms, which are usually gathered on foot in the littoral zone by women, children and older men.

Harvested species composition varies with the type of fishing gear, technique used, and location of fishing. Different fishing vessels and fishing gear are used for catching different types of fish (Jiddawi and Ohman, 2002). In our sample, the most common fishing vessels used are dugout canoes (34 percent) and outrigger canoes (21 percent). Only 24 percent of household engaged in fishing report using a dhow, large boat or engine powered boat. Roughly a fifth of the households do not use any fishing vessel, fishing on foot on the beaches or along the intertidal zones during low tides. Of those households using dugout or outrigger canoes, only a third of 
these households own or co-own the canoes they use. For the dhows, large or engine boats, the percentage of households that own or co-own these types of vessels range from 12 to 16 percent. Hence a large majority of fishing households are limited to fishing in the near shore waters.

Households use a variety of fishing gear, and frequently more than just one type of gear. The most frequently used fishing gears are hook and line fishing (33 percent) and gillnets (26 percent). Seine nets, of small and large mesh size, are used by 10 percent of households. Other types of nets, ring nets, scoop nets, and cast nets, account for another 14 percent of the fishing gear used by households in our sample. Again, a majority of households do not own the fishing gear they use. Only half own or co-own the hooks and fishing line they use, and fewer than a third own or co-won the gillnets they use. Ownership rates for other types of fishing gear are even lower.

Much of the pressure on fisheries and degradation of reef ecosystems in coastal Tanzania has been attributed to the use of fishing gear and techniques that are destructive (Jiddawi and Ohman, 2002). Dynamite fishing is one particularly destructive fishing method which has been practiced in Tanzania for over 40 years. Each blast of dynamite kills all fish and most other living organisms in a 15-20 meter radius and completely destroys the reef habitat within a radius of several meters. Mafia Bay, at one point before the Mafia Marine Park was established, was described as a war zone, with blasts going off every hour. Over a period of many years, the cumulative effect of such practices can be been devastating. In Tanga, dynamite fishing has destroyed 10 percent of reefs completely beyond recovery (Leon and others, 2004).

Other destructive fishing techniques include beach seine fishing and drag nets, as well as the use of sticks and spears. Drag nets are often weighted with chains and sticks are used to hit corals and other structures to chase fish into the net. Dragging fish nets over the reef or otherwise breaking corals destroys an important habitat for many fish, with such degradation leading to secondary effects on the productivity of the standing stock (Jiddawi and Ohman, 2002). The use of small mesh nets also results in capture of juveniles, which when conducted intensively in nursery areas can deplete fish stocks, alter species composition, leading to loss of biodiversity and disruption of food webs.

Many destructive fishing methods are illegal, but continue to be practiced due to lack of enforcement and increased competition for marine resources. About 10 percent of sampled 
households report using illegal fishing methods, such as spear gun fishing, poison fishing, and dynamite fishing. As with any household survey data, there are always concerns that households under report illegal activities for fear they or their community may be adversely affected as a result. Another reason households may under report these types of illegal fishing activities may be related to the frequency they occur. Through discussions with fisher groups and MPA management staff on the use of illegal fishing methods, we learned that these methodsparticularly dynamite fishing - tend to be used during specific times of the year (holidays, beginning of the school year) when households often need extra cash. As such, households may fail to report the use of these illegal fishing methods because they do not normally use them or simply because the last time they used such methods falls outside of the recall period. 
Table 3. Variety of marine species harvested in Tanzania

\begin{tabular}{|c|c|c|c|c|c|}
\hline English name & Local name & Representative Species & Habitat & Frequency & $\begin{array}{l}\text { Relative } \\
\text { Abundance }\end{array}$ \\
\hline Anchovy & Uono & $\begin{array}{l}\text { Stolephorus commersonii, } \\
\text { Encrasicholina punctifer, E. devisi }\end{array}$ & Pelagic & 12 & 46 \\
\hline Sea Catfish & Hongwe & Arius spp. & $\begin{array}{l}\text { Estuaries; } \\
\text { Mangroves }\end{array}$ & 14 & 41 \\
\hline Cobia & Songoro & Rachycentron canadum & Pelagic & 12 & 31 \\
\hline Crabs & Kaa & Scylla serrata & $\begin{array}{l}\text { Estuaries; } \\
\text { Mangroves }\end{array}$ & 15 & 51 \\
\hline Emperor fish & Changu & Lethrinus spp., Lutjanus spp. & Reef & 189 & 765 \\
\hline Goatfish & Mkundaji & Parupeneus indicus & Reef & 37 & 105 \\
\hline Grouper & Chewa & Epinephelus spp. & Reef & 35 & 106 \\
\hline Lobster & Kambakoche & $\begin{array}{l}\text { Panulirus ornatus, P. versicolor, P. } \\
\text { longipes }\end{array}$ & Reef & 39 & 149 \\
\hline Mackerel & Nguru & Scomberomorus commerson & Pelagic & 31 & 99 \\
\hline Mackerel & Vibua & Rastrelinger kanagurta & Pelagic & 15 & 53 \\
\hline Mojarra & Chaa & Gerres spp. & $\begin{array}{l}\text { Sandy- } \\
\text { bottom }\end{array}$ & 25 & 81 \\
\hline Mullet & Mkizi & Mugil cephalus & Pelagic & 10 & 42 \\
\hline Octopus & Pweza & Various & Reef & 122 & 491 \\
\hline Parrotfish & Pono & Leptoscarus spp. & Reef & 48 & 149 \\
\hline Pompano & Kolekole & Trachynotus sp. & Pelagic & 109 & 353 \\
\hline Rabbit fish & Tasi & Siganus spp. & Reef & 105 & 384 \\
\hline Ray & Taа & Rhinoptera javanica & Reef & 40 & 140 \\
\hline Sardine & Dagaa & Sardinella gibbosa & Pelagic & 33 & 137 \\
\hline Sea Cucumber & Jongoo & Holothuria scabra & Reef & 32 & 117 \\
\hline Shark & Papa & Various & Various & 36 & 120 \\
\hline Shell, Oyster & Chaza & $\begin{array}{l}\text { Ostrea amasa, Pinctada sp., } \\
\text { Saccostrea cucullata }\end{array}$ & $\begin{array}{l}\text { Estuaries; } \\
\text { Mangroves }\end{array}$ & 7 & 32 \\
\hline Shells & Komee & Cypraea tigris, Cypraeacassis rufa & Beach & 8 & 26 \\
\hline Snapper & Fimbo & Aprion virescens & Reef & 3 & 15 \\
\hline Snapper & $\begin{array}{l}\text { Kelea }+ \\
\text { Maginge }\end{array}$ & Lutjanus spp. & Reef & 37 & 111 \\
\hline Squid & Ngisi & & Reef & 41 & 111 \\
\hline Sweetlips & Komba & $\begin{array}{l}\text { Diagramma pictum, Plectorhinchus } \\
\text { chubbi }\end{array}$ & Reef & 7 & 20 \\
\hline Tuna & Jodari & Euthynnus sp., Thunnus sp. & Pelagic & 14 & 49 \\
\hline Unicorn fish & Puju & Naso unicornis, N. hexacanthus & Reef & 18 & 51 \\
\hline
\end{tabular}

Note: The frequency column indicates the number of households that reported normally harvesting that species, in any rank. Household ranked up to 5 species they normally harvest, in order of abundance. The relative abundance column is the sum of the ranks obtained by each species. 


\section{Empirical Strategy}

The main objective of the analysis is to examine the determinants of household choice of fishing gear. Fishing households in Tanzania use a variety of fishing gear and catch a variety of different fish and other marine products. The empirical model is based on the household production framework where households seek to maximize profits from fishing. In the standard model, with complete markets, the production decisions of the household are separable from its consumption decisions. The household maximizes profits and then maximizes utility subject to a standard budget constraint which includes the value of these profits. However, when markets are incomplete, as it is likely the case of rural coastal communities in Tanzania, the separation property breaks down and production decisions depend on the preferences and endowments of the household (Bardhan and Udry, 1999). It is in this context that we specify the empirical model for a household's demand for fishing gear.

\section{Model}

We assume the household's decision of which fishing gear $(G)$ to use is a function of a number of factors. These included fishing related factors $(F)$, household's livelihood strategies $(L)$, household endowments $(H)$, institutional factors $(I)$, village level factors $(V)$, and unobserved factors $\varepsilon$.

$$
G_{i}=G\left(F_{i}, L_{i}, H_{i}, I_{i j}, V_{v}, \varepsilon\right)
$$

We focus on fishing gear use, rather than ownership, since for most types of fishing gear, the proportion of households owning the fishing gear they use is very low. Clearly, if a household has invested resources to acquire a specific type of gear, then it will be more likely to use it. The empirical estimation of the model accounts for the impact of ownership on choice of fishing gear to use, using an instrumental variable approach. We now turn to a discussion of other factors hypothesized to influence household choice of fishing gear.

\section{$\underline{\text { Fishing factors }}$}

The choice of fishing gear to use depends on what the household intends to catch. Some types of fishing gear are specifically used to catch a certain type of fish or other marine organism 
or are used in a specific environment (shallow or deep water). One would not, for example, try to use a scoop net to catch a lobster, or set a basket trap in open deep water. Other types of gear, on the other hand, are quite versatile - a hand-line can be used from any fishing vessel or from the shore, and to fish for a variety of different fish species. Households report on the survey the five most important species they catch. These have been grouped into three types of catch: reef fish, pelagic fish, and other. Other includes marine species such as sea cucumber, crab, lobster, octopus, skid, and shells.

The choice of fishing gear to use is also influenced by the type of fishing vessel used (if any), since that may determine where the household fishes. Households fishing by a dhow or engine boat can reach further offshore, whereas households in a dugout or outrigger canoe are more restricted. Some households do not use any fishing vessel, but rather fish on foot and are mostly involved in the collection of crabs, octopus, and fish species found in shallow beach waters.

\section{$\underline{\text { Livelihood strategies }}$}

Some households are more dependent on fishing as a source of food and income than other households and we believe this can influence the choice of fishing gear. Households more dependent on fishing may also be more likely to own, and hence use, some types of fishing gear. We also consider a household's food security situation to be an important determinant of fishing gear use, with households experiencing less food security being more likely to use destructive fishing gear.

\section{Household endowments}

In the context of imperfect markets, household choice of fishing gear may be affected by the household's endowment of human, natural, physical, financial, and social capital. Household size, the age and gender of the head of the household, and the education level of household members can be thought of as the household's human capital. Land is one of the most important assets for most households - 70 percent of all households included in the survey own land, whereas 65 percent of those in the sub-sample of households involved in fishing own land. Households report the amount of land under different types of crops and the amount of land area cultivated is calculated, taking into account that some land is used for mixed cropping. 
Ownership and the amount of land cultivated are measures of natural capital at the household's disposition.

Most households in our sample do not own very many assets, particularly productive types of physical capital. For most households in our sample, a handhoe is the only agricultural assets they own. Only a handful of households own livestock or transportation equipment which could be considered as physical capital. The reported value of all household assets, including TVs, radios, household furniture, etc, were summed into one measure of physical capital. We do not include the value of fishing assets in this assets value measure, but treat those assets separately, as this is a productive factor important in determining choices regarding fishing gear use. Household's access to financial capital is proxied by whether the household has borrowed in the past, whether informally (from family or other sources) or from a credit association.

Social capital, defined as the quantity and quality of associational life and the related social norms, may also influence a household's decision of which fishing gear to use. ${ }^{6}$ Household membership in various voluntary associations or groups can be used to measure the extent or quantity of social capital. To examine the quality aspect of social capital, we consider the frequency of households' participation in village meetings. We expect households involved in more community groups and who frequently attend village meetings to be less likely to use destructive fishing gear.

\section{$\underline{\text { Institutional factors }}$}

We do not directly observe MPA patrolling activities which influence household choice of fishing gear. MPA dummies are therefore included to control for the different management approaches of each MPA, as well as other site specific factors for which we do not have data available. However, management activities of MPAs in Tanzania attempt to influence household's fishing behavior in a number of ways. Through education and awareness campaigns, MPAs provide households information on the impacts of different fishing gear and promote the use of more sustainable fishing methods. MPAs in Tanzania have created a

\footnotetext{
${ }^{6}$ The definition of social capital employed here follows the one of adopted by Narayan and Pritchett (1999) in the analysis of the impact of social capital on income of rural households in Tanzania.
} 
mechanism, to some degree or another, to involve local communities in the management process and create awareness of MPA purposed and objectives. ${ }^{7}$

MPAs, often with technical and financial assistance from NGOs, also promote alternative income generating activities (AIGA) to reduce pressure on fisheries resources. A broad range of activities fall under these $A I G A$ strategies, some of which are alternatives to fishing (beekeeping, tree planting, farming, direct employment in MPA, etc), while others are alternatives to improve fishing practices, such as through fishing gear exchanges or loans to acquire specific fishing equipment to allow offshore fishing. We expect involvement and awareness of MPA activities, and participation in AIGA to positively influence household fishing gear choices.

\section{Other control factors}

The survey design included control villages that were located outside of the MPAs included in the study. In Kilwa, since there is no MPA, all villages are considered control villages. This provides a comparison group to evaluate whether MPAs have an impact on household fishing gear choice through other means which are not captured in the questions posed in the household questionnaire.

We also examine the impact of household choice of fishing gear on household welfare. If destructive fishing gear types are more productive, then one would naturally expect that households' motivation to use such gears is the realization of a higher income. We use per capita consumption as a measure of household welfare rather than income, however, as extensive experience with household surveys has shown that income data are often more susceptible to measurement error and show more variance, due to saving and consumption smoothing behavior (Deaton, 1997). We follow the standard specification adopted in many poverty assessments, and which has been previously used in a study of rural poverty in Tanzania (Narayan and Pritchett, 1999). In this framework, consumption is determined by the households endowments of human $(\mathrm{H})$, natural $(\mathrm{N})$, social $(\mathrm{S})$, physical $(\mathrm{K})$, and financial $(\mathrm{F})$ capital, and the constraints present in their socioeconomic and physical environment $(Z)$.

\footnotetext{
${ }^{7}$ The Tanga Coastal Zone Conservation and Development Program, on one hand, follows a highly decentralized model of community based costal management, where communities alone decide on nearly all aspects of fisheries management in their area. In other MPAs, such as Misali Island and Menai Bay Conservation Areas, the management model involves co-management at three levels, local, district, and national. Households may also be involved in the MPA management activities through less formal methods, by attending MPA public meetings.
} 


$$
C_{h}=C\left(G_{h}, H_{h}, N_{h}, S_{h}, K_{h}, F_{h}, \mathrm{Z}_{h v}, u_{h}\right)
$$

where

$G_{h}: \quad$ denotes the household's choice of fishing gear;

$H_{h}$ : mean education level of adult males and adult females in the household, household size, dependency ratio (number of young and old relative to number of adults), age, gender, and education of household head;

$N_{h}$ : whether household owns land and amount of land farmed under various crops;

$S_{h}$ : $\quad$ social capital is measured by the number of groups the household belongs to and households' participation in village assembly meeting;

$K_{h}$ : value of assets owned by household, which includes home assets (televisions, radio, furniture, bicycle, etc) and productive assets (tools used for agricultural production, fishing nets and boats, etc);

$F_{h}$ : whether household has taken a loan and/or belongs to a savings and credit program;

$Z_{h}$ : distance from village to various social services (bus, hospital, markets), village population, whether village inside MPA.

\section{Econometric Specification}

The primary goal of the analysis is not so much to explain the household's choice of a particular gear, but rather household's choices of fishing gear that are particularly environmentally destructive. Therefore we classify the different types of gears into two groups: destructive and non-destructive fishing gears. Fishing gear is considered environmentally destructive if their use results in large amounts of by-catch of non-target species or cause degradation of the coastal environment. We classify dynamite, poison, spear guns, gillnets, seine nets, drive nets, and shark nets as environmentally destructive fishing gear. Some of the gears classified as destructive fishing gear, such as dynamite, poison, spear gun, and beach seining are in fact illegal because of their negative environmental impacts. Others, such as gillnets, drive nets, and shark nets are not illegal, but their use is regulated due to their potential negative 
impacts on the environment. ${ }^{8}$ For example, fishing nets have to be of a specific mesh size (to prevent catch of juvenile species) and their use is often restricted in sensitive habitats - such as beaches, coral reefs, and spawning grounds.

In assessing the potential negative impact of different fishing gears on the environment, we rely on information collected during our focus group survey about how these different gears are actually used, as well as other studies that have taken place in Tanzania. Evidence suggests that there is a lack of compliance with some fishing gear regulations, and some illegal methods and gear continue to be used due to lack of enforcement and public awareness (Jiddawi and Ohman, 2002). Seine nets of small mesh size are commonly used and dragged on beaches and coral reefs, and sometimes even mosquito nets are used (MANREC, 2005; Berachi, 2003). Therefore, we classify gillnets, beach seine nets, and drive nets, as destructive fishing gears despite their legal status, because the way they are used are likely to cause significant environmental damage. This is in addition to illegal fishing gear, such as dynamite and poison, which are also considered destructive fishing gear. ${ }^{9}$

Environmentally non-destructive fishing gear, on the other hand, are the types of fishing gear that are selective in catching the targeted species and do not result in large amounts of bycatch or result in negative impacts on marine habitats. We classify scoop nets, cast nets, ring nets, traps, fences, and hook and line fishing, as environmentally non-destructive fishing gear. As with the classification of environmentally destructive fishing gear, determining which types of gear are less destructive and belong in the non-destructive fishing gear category involves some judgment about how these gears are actually used in practice. Most of these gears we classify as non-destructive have traditionally been used by local fishermen. While they may generate some negative environmental impacts if used carelessly or by too many fishermen, the gears by themselves do not generate substantial habitat destruction.

\footnotetext{
${ }^{8}$ The FAO's Fisheries Global Information System contains detailed fishing gear type fact sheets, which includes a description of the fishing gear, how it is used, and an assessment of the gear's impact on the catch of juveniles and other species and the marine environment.

${ }^{9}$ We should note that dynamite and poison fishing are likely underreported in our survey. We believe this is case for two reasons. First, households may be less likely to report they use these methods simply because these are known to illegal activities. Second, dynamite use is very seasonal. Marine park police report that use of dynamite fishing increases at specific times of the year-such as when school fees are due or during particular holidays, when households may be in need of extra cash. The timing of our survey and recall period of one month would therefore miss this type of sporadic use.
} 
Let $y=1$ represent a household's use of environmentally destructive fishing gear and $y=0$ the use of non-destructive fishing gear. We can estimate the probability a household chooses to use environmentally destructive fishing gear, which is given by:

$$
\operatorname{Prob}(y=1)=\Phi\left(\beta^{\prime} x_{i}\right)
$$

Where $\Phi$ represents the cumulative normal standard distribution and $x_{i}$ the vector of independent variables, fishing related factors, household's livelihood strategies and endowments, institutional factors, village factors, discussed earlier.

However, we should consider the possibility that the household's choice of fishing gear and type of fish to catch may be simultaneously determined. Results of the factor analysis of fishing technology and target species for households involved in fishing shows that a high proportion of the variation in fishing characteristics falls into logical groupings, in terms of reliance on near shore resources and use of specific fishing technology. This suggests decisions concerning where to fish, what type of species to target, and gear used are closely linked. In this case, we would then have to specify the following model:

$$
\begin{aligned}
& y_{1}^{*}=\beta_{1} y_{2}^{*}+\gamma_{1}^{\prime} x_{1}-u_{1} \\
& y_{2}^{*}=\beta_{2} y_{1}^{*}+\gamma_{2}^{\prime} x_{2}-u_{2} \\
& y_{i}= \begin{cases}1, & \text { if } y_{i}^{*}>0 \\
0, & \text { otherwise }\end{cases}
\end{aligned}
$$

Where $y_{1}$ denotes the choice of fish to target (pelagic or reef) and $y_{2}$ denotes the choice of fishing gear. We estimate this structural model as a bivariate probit model and test the hypothesis that the choice of fishing gear and target fish species are simultaneously made by households. Assuming that $u_{1}$ and $u_{2}$ are jointly normally distributed with mean zero, the covariance matrix is given by:

$$
\left[\begin{array}{cc}
1 & \rho \\
\rho & \sigma_{u}
\end{array}\right]
$$


The correlation coefficient $\rho$ accounts for the possibility that these two decisions are simultaneously made by households, hence we test the hypothesis that $\rho=0 .{ }^{10}$

We also estimate a reduced form univariate probit model, which allows direct estimation of the impact of fish target species on the probability of using destructive fishing gear. In order to ensure logical consistency (so as to ensure that probabilities sum to one), we consider the model where $\beta_{1}=0 .{ }^{11}$ We can then specify the following reduced form equation:

$$
y_{2}^{*}=\beta_{2} \tilde{y}_{1}+\gamma_{2}^{\prime} x_{2}-u_{2}
$$

where

$$
\widetilde{y}_{1}=\operatorname{Pr} o b\left(y_{1}^{*}>0\right)
$$

This formulation of the model can also be estimated using the probit maximum likelihood estimator (MLE) and results in consistent estimates of equation (7) parameters (Maddala, 1983). ${ }^{12}$

Equation (2) is first estimated by the standard OLS method adopted in poverty analysis. We also estimate the determinants of consumption using a MLE, since some of the variables which determine the choice of fishing gear may also determine household consumption. The MLE directly controls for the part of the error term in equation (2) which is correlated with household's choice of fishing gear. ${ }^{13}$

\footnotetext{
${ }^{10}$ If $\rho=0$, then the sum of the $\log$ likelihoods of probit estimation of equations (3) and (4) will equal the $\log$ likelihood of bivariate probit model.

${ }^{11}$ We must assume that either $\beta_{1}$ or $\beta_{2}$ be equal to zero to specify a univariate probit equation. This is known as an identifiability condition, necessary to estimate all parameters in equation (7). For a full discussion of these conditions and other assumptions necessary identify and estimate simultaneous equation models, see Maddala (1983).

${ }^{12}$ If $u_{1}$ and $u_{2}$ are independent, then one can estimate both equations separately using a probit ML method. If $u_{l}$ and $u_{2}$ are not independent, the two stage method, in which we first obtain the probit ML estimates of $\hat{\gamma}_{1}$ of $\gamma_{1}$ and then substitute $\Phi\left(\hat{\gamma}_{1}^{\prime}, x_{1}\right)$ for $y_{1}^{*}$, does not give consistent estimates of the parameters. To be conservative, we do not assume the error terms are independent but rather employ the substitution of $\Phi\left(\gamma_{1}^{\prime}, x_{1}\right)$ for $\tilde{y}_{1}$ which Maddala (1983) shows results in consistent estimates of the model's parameters.

${ }^{13}$ The MLE uses a two step iterative procedure. In the first step the part of the error term which is correlated with the choice of fishing gear is estimated using a probit model. Household consumption is estimated in the second step, with a correction for the effect of the choice of fishing gear. The error term in the second step estimation of equation (2) is therefore not correlated with the choice of fishing gear.
} 


\section{Estimation issues}

In addition to the potential simultaneous determination of fishing gear used and the choice of fish to target, and the impact of the choice of fishing gear on household consumption levels, we must also address the implications of the survey design and possible endogenous variables in the econometric estimation of the models in equations (2) - (9).

Because the survey design sampled clusters of households in a given village, it violates the assumption of independent observations. Households in a given cluster are more likely to be similar to one another in some respects than households in different clusters. For example, households in a given village may face similar constraints, such as a heavily degraded reef fisheries or not being able to access a particular type of fisheries due to geographical constraints. The error terms in the regression ignoring the cluster effect will be correlated across observations in the same cluster, and hence the efficiency of the coefficients estimated will be affected (Deaton, 1997). Ignoring the cluster effect increases the variability of standard error estimates compared with a simple random sampling design. However, the model can be estimated using appropriate statistical techniques. These will estimate the $\beta$ vector that maximizes the likelihood function that we would have if we had data on all individuals in the population. The variance estimates are computed as if the sample was drawn again and again using the same clustering scheme and the estimated $\beta$ vector computed as the maximum of the "pseudo-likelihood" function. ${ }^{14}$

Inclusion of household's ownership of fishing gear as an explanatory variable can potentially bias the estimated coefficients. Household's ownership of fishing gear may be endogenously determined by household's characteristics-livelihood strategies and endowments - in which case, the error terms in the regression will be correlated with the ownership variable. If this correlation between the error term and one of the explanatory variables is not controlled for in the estimation procedure, then estimated coefficients could be biased. Table A2, in the annex, presents the results of different model specifications tried to control for the impact of ownership. We chose an instrumental variables approach to address this potential endogeneity problem. Village level variables and factor analysis scores for household's

\footnotetext{
${ }^{14}$ The STATA 7.0 manual contains a more detailed discussion of the survey estimation commands that can be used in this case.
} 
wealth and fishery characteristics that are excluded from the bivariate and univariate probit analysis are used as instruments to predict ownership of fishing gear. Such variables are significant predictors of household ownership of fishing gear, but do not add significantly to the prediction of fishing gear use after controlling for the other variables that are included in the model.

\section{Results}

The results of the analysis of household's use of destructive fishing gear are presented in Tables 4 and 5. We first report the results for the estimation of equations (4) and (5), using a bivariate probit model for the simultaneous choice of fishing gear and targeting of reef and pelagic species. These results are presented in Table 4. In principle, a multivariate probit model that accounts for the simultaneous decision of targeting reef species, pelagic species, and use of destructive fishing gear, would be just an extension of the bivariate probit model. However, the practical obstacle to estimating such a multivariate probit model is the evaluation of higher order multivariate normal integrals. Existing techniques do not allow accurate and efficient evaluation for more than two variables, even in a sample of moderate size (Greene, 1997). Since some households report catch of both reef and pelagic species, we estimated separately the choice of fishing gear for reef and pelagic species.

The results of the bivariate models for reef and pelagic species are broadly consistent and most of the variables statistically significant as determinants of use of destructive fishing gear for reef species (column I) are also statistically significant in the use of destructive fishing gear for pelagic species (column III). We reject the hypothesis that the choice of fishing gear used is independent of targeting reef species. In other words, there is a degree of correlation between the choice of fishing gear used and the probability of fishing for reef species, suggesting these decisions are jointly made. As for pelagic species, the choice of fishing gear is independently made of the choice to fish pelagic species. We now discuss the impact of specific variables on the probability of using destructive fishing gear.

Ownership is an important determinant of destructive fishing gear use. Accounting for the impact of ownership also has an impact on the estimated coefficient of other fishing related factors. In general, failure to account for the impact of ownership overstates the magnitude of the 
impact of other fishing related factors (see Table A2). Households that do not own their fishing gear, but rather "rent" the gear they use, also have a positive probability of using destructive fishing gear. ${ }^{15}$ However, the impact of ownership on use of destructive fishing gear is larger than if the gear is rented.

Households that use an outrigger or dugout canoe are significantly more likely to use destructive fishing gear. Households using canoes have a slightly higher probability of fishing reef species, whereas households using larger boats have a slightly higher probability of fishing pelagic species. This makes sense, and confirms fishermen's statements that they lack equipment to fish further offshore, thereby putting increasing pressure on near shore fisheries resources. The higher probability of using destructive fishing gear when fishing for reef species in near shore waters is likely to exacerbate the pressure on near shore fisheries. Once we control for ownership of fishing gear, households dependent on fishing as a primary source of income are no more likely to use destructive fishing gear as other households also engaged in fishing. Household more dependent on fishing, however, are more likely to target pelagic species.

Results regarding household characteristics suggest that some aspects of poverty may contribute to environmental degradation. Households able to satisfy their normal diet most of the time during the past year are significantly less likely to use destructive fishing gear. This result could be interpreted as supporting the hypothesis that poverty leads to environmental degradation - at least extreme poverty, as measured by a household's inability to achieve food security. Larger household and female headed households, who are generally poorer, are also more likely to use destructive fishing gear. ${ }^{16}$ Higher mean male education reduces the probability a household uses destructive fishing gear, although the coefficient on this variable is rather small. Female education is not a significant determinant of choice of fishing gear. Wealthier households, in terms of value of physical assets, are less likely to use destructive fishing gear. Access to credit, on the other hand, increases the probability of using destructive fishing gear. Land ownership and the amount of land cultivated are not significant determinants of the use of destructive fishing gear.

\footnotetext{
${ }^{15}$ Individuals may rent fishing gear for a fee, or, as it is more often the case, use fishing gear provided by a fish trader subject to an agreement to sell all or most of its catch to the trader at an agreed below market price.

${ }^{16}$ From our survey questionnaire, we cannot determine which household member uses a particular type of fishing gear. Therefore the finding that female households are more likely to use destructive fishing gear does not imply that females are more likely to use destructive gear. In Tanzania, females are generally not directly involve in fishing, other than collecting seashells, sea cucumbers, and octopus for a few hours a day during the spring tides.
} 
Households living in a village inside a MPA are significantly less likely to fish for reef species. This suggests that MPA restrictions may be effective in determining the location of fishing activities However, village location inside the MPA has no direct impact on the choice of fishing gear. It is possible that MPAs' impact on fishing gear occurs indirectly, for example, by supporting AIGA. These programs often support fishing gear exchange programs, as well as diversification of income generating activities away from fishing. We find that AIGA reduce the probability that households use destructive fishing gear. Together these results would suggest that MPAs may be reducing pressure on near shore fisheries, at least to the extent that they influence the location of fishing for households living within their boundaries and the choice of fishing gear for those participating in AIGA. Awareness of MPA objectives and purpose of management activities does not have a significant impact on choice of fishing gear and species targeted.

Next we discuss the results of estimating equation (7), the reduced form univariate probit model of the use of destructive fishing gear. These results are presented in Table 5. The reduced form model presented in equation (7) is estimated based on the results of the bivariate probit mode, which suggests that the choice of gear to use and the choice to fish reef species are simultaneously made. Therefore, the reduced form model estimated takes into account the correlation between the use of destructive fishing gear and targeting of reef species. Most of the coefficients reported in Table of 5 are very close to the results reported earlier for the bivariate instrumental variable probit model. This suggests that the inclusion of the predicted probabilities for reef species do not bias the coefficients of the other explanatory variables.

One of the benefits of estimating the reduced form univariate probit model is that we can calculate the marginal probabilities associated with each of the explanatory variables and compare the impact changes in these variables on the probability a household uses destructive fishing gear. As the results reported in Table 5 confirm, the most important determinant of whether a household uses destructive fishing gear is ownership of such gear. A household that owns destructive fishing gear is 89 percent more likely to use such gear than households that does not own destructive fishing gear. Households that do not own the fishing gear they use, but rather rent such gear, are only 54 percent more likely to use destructive fishing gear. These results suggest that policies to enforce existing fishing gear regulations that ban the use of these 
destructive fishing gears and facilitate the ownership of less destructive fishing gear (such as gear exchange programs) are likely to have the most impact in the use of destructive fishing gear.

Households that fish reef species are four times more likely to use destructive fishing gear (20 percent) than households fishing for pelagic species (5 percent). However, we should note that the coefficient on the pelagic variable is not statistically significant. Although the probability of using destructive fishing gear is nearly the same for households using large boats and those using canoes, only the use of a canoe is a statistically significant determinant of the use destructive fishing gear. Given that households using canoes are more likely to fish in the near shore waters and target reef species, this may suggest that pressure on near shore fisheries resources is further exacerbated by lack of equipment to reach further offshore.

Female headed households are frequently the poorest and most dependent on near shore resources as an important source of food and income. Women in Tanzania generally do not participate directly in fishing, but rather are involved in the collection of seashells, sea cucumber, and octopus, for a few hours a day during the spring tides. Although we cannot distinguish which household members use which gears, our results show that female headed households are 26 percent more likely to use destructive fishing gear. Achieving food security reduces the probability that a household uses destructive fishing gear by 10 percent. Other variables, such as male education, value of physical assets, are also significant determinants of destructive fishing gear use. Their negative coefficient suggests that wealthier, more educated households are less likely to use destructive fishing gear. However, the magnitude of the impact of male education and value of assets is relatively small. Still, these results would tend to support the hypothesis that poverty may lead to environmental degradation. However, in contrast, access to credit increases the probability of using destructive fishing gear by 10 percent. The relationship between different aspects of poverty and the use destructive fishing gear is thus complicated.

Household participation in AIGA has a surprisingly large impact on household choice of fishing gear-reducing the probability of use of destructive fishing gear by 13 percent. Promotion of AIGA is often viewed as an essential instrument to achieve conservation objectives in MPAs, by addressing the poverty related root causes that may be the driving force behind some of the habitat degradation in coastal areas. Directly measuring the success of such measures on reducing habitat degradation is often difficult. This result suggests that MPA 
supported activities in Tanzania that provide incentives for households to develop AIGA do influence household fishing gear choice. The proportion of households participating in these AIGA amounts to 16.5 percent of households living in MPA villages. Unfortunately the survey does not provide any detailed information on what type of AIGA the household is involved. We do not find any significant impact of household awareness of MPA affairs or whether the household lives in a village inside a MPA. 
Table 4: Bivariate probit model of the use of destructive fishing gear

\begin{tabular}{|c|c|c|c|c|c|c|c|c|}
\hline & \multicolumn{2}{|c|}{$\begin{array}{l}\text { Use Destructive } \\
\text { Fishing Gear (I) }\end{array}$} & \multicolumn{2}{|c|}{$\begin{array}{c}\text { Fish Reef } \\
\text { Species (II) }\end{array}$} & \multicolumn{2}{|c|}{$\begin{array}{c}\text { Use Destructive } \\
\text { Fishing Gear(III) }\end{array}$} & \multicolumn{2}{|c|}{$\begin{array}{l}\text { Fish Pelagic } \\
\text { Species (IV) }\end{array}$} \\
\hline $\begin{array}{c}\text { Independent } \\
\text { Variables }\end{array}$ & Coefficients & $\begin{array}{r}\text { Standard } \\
\text { Errors } \\
\end{array}$ & Coefficients & $\begin{array}{r}\text { Standard } \\
\text { Errors } \\
\end{array}$ & Coefficients & $\begin{array}{r}\text { Standard } \\
\text { Errors }\end{array}$ & Coefficients & $\begin{array}{r}\text { Standard } \\
\text { Errors }\end{array}$ \\
\hline \multicolumn{8}{|l|}{ Own destructive fishing gear (IV } & 0.341 \\
\hline Rent fishing gear & $1.727 * * *$ & 0.232 & 0.287 & 0.330 & $1.741 * * *$ & 0.236 & $0.534 * *$ & 0.249 \\
\hline Large boat/dhow & 0.515 & 0.320 & $0.817 * * *$ & 0.222 & 0.458 & 0.321 & $1.139 * * *$ & 0.305 \\
\hline Outrigger or dugout canoe & $0.567 * * *$ & 0.192 & $1.184 * * *$ & 0.209 & $0.523 * * *$ & 0.199 & $1.077 * * *$ & 0.250 \\
\hline Fishing primary activity & 0.174 & 0.244 & 0.281 & 0.185 & 0.150 & 0.250 & $0.474 * *$ & 0.222 \\
\hline Food secure & $-0.404 * *$ & 0.211 & -0.114 & 0.256 & $-0.398 *$ & 0.245 & $-0.259 *$ & 0.155 \\
\hline Household size & $0.074 * *$ & 0.028 & 0.006 & 0.033 & $0.068 * *$ & 0.025 & -0.020 & 0.034 \\
\hline Female head of household & $0.883 * * *$ & 0.228 & -0.357 & 0.393 & $0.900 * * *$ & 0.245 & -0.176 & 0.397 \\
\hline Mean male education & $-0.073 * *$ & 0.037 & 0.020 & 0.023 & $-0.077 * *$ & 0.037 & -0.006 & 0.029 \\
\hline Mean female education & 0.042 & 0.029 & -0.017 & 0.026 & 0.046 & 0.028 & -0.024 & 0.025 \\
\hline Own land & -0.231 & 0.276 & -0.111 & 0.201 & -0.249 & 0.277 & -0.099 & 0.123 \\
\hline Land area cultivated & -0.002 & 0.026 & 0.008 & 0.018 & -0.011 & 0.025 & $0.029 *$ & 0.017 \\
\hline Access to credit & $0.465 * *$ & 0.229 & $0.250 *$ & 0.141 & $0.439 * *$ & 0.218 & -0.064 & 0.179 \\
\hline Value of physical assets & $-3.04 \mathrm{e}^{-07^{* *}}$ & $1.77 \mathrm{e}^{-07}$ & $-5.05 \mathrm{e}^{-07 * * *}$ & $1.75 \mathrm{e}^{-07}$ & $-3.26 \mathrm{e}^{-07 *}$ & $2.02 \mathrm{e}^{-07}$ & $-1.17 \mathrm{e}^{-07 * *}$ & $8.42 \mathrm{e}^{-07}$ \\
\hline Participates in village meetings & 0.098 & 0.064 & -0.004 & 0.043 & 0.101 & 0.066 & $-0.166^{* * *}$ & 0.058 \\
\hline Participates in AIGA & $-0.993 * * *$ & 0.330 & 0.203 & 0.193 & $-0.978 * * *$ & 0.318 & 0.248 & 0.263 \\
\hline Aware of MPA affairs & -0.054 & 0.213 & 0.145 & 0.213 & -0.055 & 0.191 & -0.091 & 0.193 \\
\hline MPA village & 0.189 & 0.201 & $-0.399 * * *$ & 0.163 & 0.201 & 0.201 & -0.181 & 0.131 \\
\hline Observations & 655 & & 655 & & 655 & & 655 & \\
\hline Log likelihood & -5337 & & & & -5156 & & & \\
\hline Wald test of rho $=0$ : & $\operatorname{chi}^{2}(1)=5.0$ & Prob $>$ chi $^{2}$ & $=0.02$ & & $\operatorname{chi}^{2}(1)=1.1$ & rob $>\mathrm{chi}^{2}$ & $=0.28$ & \\
\hline \multicolumn{8}{|c|}{$\begin{array}{l}\text { Notes: } \\
* * *, * *, * \text { indicate significance at the } 99,95, \text { and } 90 \text { percent confidence interval, respectively }\end{array}$} & \\
\hline
\end{tabular}


Table 5: Reduced form probit model of the use of destructive fishing gear

\begin{tabular}{lccc}
\hline \multicolumn{1}{c}{ Independent } & \multicolumn{3}{c}{ Use Destructive Fishing Gear } \\
\hline Variables & Coefficients & Standard Errors & Marginal \\
Owobabilities
\end{tabular}

Notes:

$* * *, * *, *$ indicate significance at the 99,95 , and 90 percent confidence interval, respectively

Robust standard errors reported, adjusted for clustering effect

Coefficient for dummy variables for each of the MPAs and constant not reported

For continuous variables, marginal probabilities measure the marginal change in probability at the variable's mean. For discrete variables, the marginal probabilities should be interpreted as the change in probability for a change of the dummy variable from 0 to 1 
Table 6 shows the results of the estimation of equation (2), the consumption equation. ${ }^{17}$ We first estimate equation (2) by OLS, using the standard specification adopted in these types of poverty analysis. We find that larger households, households with a higher ratio of dependents to working adults, and households headed by a female have lower consumption levels. Households with an older head also have lower consumption levels, although this effect diminishes as the household head ages. The average household head is 44 years old. The education level of the head of household head matters. Literacy in Kiswahili or English is positively correlated with household consumption. Surprisingly, however, the education levels of other household members do not show a significant impact on household consumption.

Households primarily dependent on farming for income generation have significantly lower levels of consumption than households in other sectors. This result is consistent with the finding of the analysis of the national 2000/01 Household Budget Survey (HBS), which shows that poverty is highest among farming households (NBS, 2002). Households primarily dependent on fishing for income generation are neither worse off nor better off, in terms of consumption levels, than households in other occupations. Rural households depend on a variety of income sources. After controlling for household size and number of productive adults relative to the number of dependents, the results on Table 6 show that having such a diversified income base increases household consumption levels. This finding is also consistent with findings of the 2000/01 national HBS. However, nationally 65 percent of households report 3 or more income sources. In our sample of the coastal population, only about half of the households surveyed report having 3 or more income sources. Providing opportunities for income diversification along the coast should therefore increase consumption levels and reduce poverty.

Households with more assets also have higher consumption levels, despite the very low level of ownership of productive assets. Surprisingly, land ownership and the amount of land farmed do not significantly impact household consumption. Despite experimenting with several alternative measures for social capital, in general, social capital does appear to have a

\footnotetext{
${ }^{17} \mathrm{We}$ do not report results with village distance variables as in nearly all instances these variables were statistically insignificant. We drop the distance variables from the analysis because missing distance data for some villages resulted in a large number of observations being excluded from the analysis.
} 
significant influence on household consumption levels. The frequency of household's participation in village meetings is statistically significant in the OLS model, but only at the 10 percent level.

The comparison between households living in an MPA village and those living outside an MPA area show that households in the MPA villages have, on average, lower consumption levels. That is not to say that MPAs cause lower levels of consumption, since these households might have had lower consumption levels perhaps even before the MPAs were established. Other characteristics of these villages which are not accounted for in the model estimated could also be partly driving this result. However, this finding does raise enough concern so that the impact of MPAs on household consumption and other household welfare measures should be investigated further.

The results discussed above remain consistent in the other specifications of the consumption equation (2) reported on Table 6, which explore the impact of the use of destructive fishing gear on households' consumption levels. However, the OLS results and MLE results lead to very different conclusions regarding the impact of the use of destructive fishing gear. When the consumption equation is estimated by OLS and includes the choice of fishing gear, the use of destructive fishing gear has no significant impact on household's consumption levels. This is the case in the OLS model even if we restrict the sample to fishing households only. But we know from the earlier results (Tables 4 and 5) that the use of destructive fishing gear is at least partly determined by some of the exogenous variables included in the consumption equation. In other words, the use of destructive fishing gear is endogenously determined.

If individuals choose whether or not to use destructive fishing gear and the error term of the model that gives rise to this choice is correlated with the error term in the consumption equation, then we can expect that the OLS estimate of the impact of the use of destructive gear on consumption to be biased. The MLE adopts an iterative estimation procedure which corrects for the correlation between the use of destructive fishing gear and error term in the consumption equation. Thus the MLE provides a consistent (or unbiased) estimate of the impact of the use of destructive fishing gear on household consumption (Maddala, 1983). As the results on Table 6 shows, the MLE estimate of the impact on household consumption of 
the use of destructive fishing gear is about twice as large as the OLS estimate. The downward bias in the coefficient on the use of destructive fishing gear in the OLS model suggests there is a negative correlation between household consumption and the use of destructive fishing gear. Correcting this bias with the MLE, we reject the hypothesis that the use of destructive fishing gear has no impact on household consumption. The MLE estimate of the impact of the use of destructive fishing gear suggests that, holding all other factors constant, is to increase household consumption by 7 percent.

The correlation of the error terms in equation (2) and equation (8) is not strong enough to reject the hypothesis that the two error terms are uncorrelated. However, the amount of correlation between the two error terms is enough to bias the coefficient of the use of destructive fishing gear and render it statistically insignificant in the OLS equation. In a way, this result suggests that although household consumption is determined independently of the choice of fishing gear, there is still a small "income effect" for those that use destructive fishing gear. If there were no such correlation two error terms, the MLE and the OLS methods would both produce unbiased coefficient estimates for the variable on the use of destructive fishing gear. 
Table 6: Determinants of household consumption

\begin{tabular}{|c|c|c|c|c|c|c|}
\hline \multirow[b]{2}{*}{$\begin{array}{c}\text { Independent } \\
\text { Variables }\end{array}$} & \multicolumn{2}{|c|}{$O L S(I)$} & \multicolumn{2}{|c|}{$O L S(I I)$} & \multicolumn{2}{|c|}{$M L E$ (III) } \\
\hline & Coefficients & $\begin{array}{r}\text { Standard } \\
\text { Errors } \\
\end{array}$ & Coefficients & $\begin{array}{r}\text { Standard } \\
\text { Errors }\end{array}$ & Coefficients & $\begin{array}{r}\text { Standard } \\
\text { Errors } \\
\end{array}$ \\
\hline Uses destructive fishing gear & & & 0.028 & 0.033 & $0.074 * *$ & 0.031 \\
\hline Household size & $-0.084 * * *$ & 0.013 & $-0.085 * * *$ & 0.013 & $-0.086^{* * *}$ & 0.013 \\
\hline Dependent ratio & $-0.275^{* * *}$ & 0.093 & $-0.272 * * *$ & 0.093 & $-0.276^{* * *}$ & 0.093 \\
\hline Female head of household & $-0.215 * *$ & 0.090 & $-0.221 * *$ & 0.090 & $-0.229 * * *$ & 0.092 \\
\hline Household head's age & $-0.022 * *$ & 0.009 & $-0.023 * *$ & 0.008 & $-0.022 * * *$ & 0.008 \\
\hline Head's age squared & $0.000 * *$ & 0.000 & $0.000 * *$ & 0.000 & $0.000 * *$ & 0.000 \\
\hline Household head literate & $0.105^{* *}$ & 0.049 & $0.102 * *$ & 0.044 & $0.099 * *$ & 0.042 \\
\hline Mean male education & 0.001 & 0.006 & 0.001 & 0.006 & 0.001 & 0.006 \\
\hline Mean female education & -0.004 & 0.005 & -0.004 & 0.005 & -0.005 & 0.005 \\
\hline Farmer & $-0.148 * *$ & 0.059 & $-0.150 * *$ & 0.059 & $-0.152 * * *$ & 0.059 \\
\hline Fisher & -0.055 & 0.062 & -0.064 & 0.064 & -0.079 & 0.063 \\
\hline Employed & 0.050 & 0.053 & 0.047 & 0.054 & 0.042 & 0.055 \\
\hline Number of income sources & $0.040 * * *$ & 0.014 & $0.039 * * *$ & 0.014 & $0.040 * * *$ & 0.014 \\
\hline Access to credit & -0.111 & 0.075 & -0.114 & 0.074 & -0.116 & 0.073 \\
\hline Own land & 0.068 & 0.062 & 0.068 & 0.063 & 0.069 & 0.063 \\
\hline Value of physical assets & $8.8 \mathrm{e}^{-8 * * *}$ & $3.3 \mathrm{e}^{-8}$ & $8.8 \mathrm{e}^{-8 * * *}$ & $3.3 \mathrm{e}^{-8}$ & $8.9 \mathrm{e}^{-8 * * *}$ & $3.3 \mathrm{e}^{-8}$ \\
\hline Participates in village meetings & $0.026^{*}$ & 0.015 & $0.024^{*}$ & 0.015 & 0.023 & 0.015 \\
\hline Participates in AIGA & 0.018 & 0.072 & 0.020 & 0.072 & 0.022 & 0.073 \\
\hline MPA village & $-0.125^{* * *}$ & 0.029 & $-0.121 * * *$ & 0.031 & $-0.114^{* * *}$ & 0.031 \\
\hline Observations & 648 & & 648 & & 648 & \\
\hline R Square/ Log likelihood & 34.75 & & 34.79 & & -6411 & \\
\hline $\begin{array}{l}\text { Notes: } \\
* * *, * *, * \text { indicate significance } \\
\text { Robust standard errors reported, } \\
\text { Coefficient for dummy variables }\end{array}$ & $\begin{array}{l}99,95, \text { and } \\
\text { ed for cluste } \\
\text { ch of the M }\end{array}$ & $\begin{array}{l}\text { ent confiden } \\
\text { ect } \\
\text { constant no }\end{array}$ & $\begin{array}{l}\text { erval, respe } \\
\text { orted }\end{array}$ & & & \\
\hline
\end{tabular}




\section{Conclusion}

In many tropical developing countries poverty is believed to be the main driving force behind the degradation of marine and coastal environment. There is also concern that if policies adopted to address degradation of these resources do not take into consideration the poverty issues, they will be less likely to be effective and lead to greater poverty and marginalized livelihoods for those that depend on these resources. Using household survey data from coastal areas of Tanzania, this paper examines the linkages between poverty, MPA management activities and household use of destructive fishing gear. Our goal is to understand whether poverty contributes to the use of destructive fishing gear and how MPA activities impact household choice of fishing gear and household welfare.

While we cannot establish a direct link between income poverty and the use of destructive fishing gear, we do find that some aspects of poverty contribute to the use of destructive fishing gear. Poverty has many different dimensions, and hence we examine a number of measures of poverty in the analysis to understand how different aspects of poverty affect household fishing gear use. We find that food insecure households and female headed households are more likely to use destructive fishing gear. Higher levels of male education and higher asset wealth, on the other hand, decrease the probability that households use destructive fishing gear.

We also find that ownership of fishing gear matters. Households that own destructive fishing gear are virtually certain to use such gear. However, more than two-thirds of fishing households do not own the fishing gear they use. These households are only slightly more likely to use destructive fishing gear than not. Most of the fishing gear we classified as destructive also happens to be illegal. Enforcement of existing regulations banning the use of the illegal fishing gear is clearly important, but so is perhaps a policy that confiscates illegal gear. Fines and other types of punishment may do little to deter the use of illegal gear,

particularly when the illegal fishing gear can be rented out. For other destructive fishing gear that is not illegal, a gear exchange program might be considered. Some MPAs in Tanzania do in fact already have such gear exchange programs, which are facilitating the exchange of destructive fishing gear for more environmentally sustainable fishing gear. Households that use destructive fishing gear do appear to benefit from it, at least to some degree, in terms of 
higher household consumption. Therefore incentives are also needed to dissuade the use of such gear, in addition to stricter enforcement of existing regulations.

An interesting finding of our analysis shows that households participating in AIGA promoted by MPAs are less likely to use destructive fishing gear. This is an encouraging result given that MPAs in Tanzania support a broad range of AIGA, aimed at reducing pressure on fisheries through the development of new activities, as well as activities to improve the sustainability of fishing practices. We also find that households living in MPA villages are less likely to target near shore reef species. Whether these impacts are sufficiently large to generate desired environmental outcomes and whether they would hold if resources were available to expand such AIGA are clearly important questions to be considered. Further analysis with relevant environmental indicators would be needed to determine to what extent MPA management activities contribute to lower pressure on coastal resources in these areas.

MPA management policies restrict access to fishing in some areas, and this may have an adverse impact on households dependent on fishing for their livelihoods. At the same time, other economic opportunities may arise as a result of MPA activities. Our data suggest that the proportion of households employed in non-fishing and non-farming activities are two to three times higher for MPA villages than for non-MPA villages. We do not find any evidence that fishing households in general, or fishing households in MPA areas, are worse off compared to other occupations. This is reassuring. However, households residing in MPA villages have lower levels of consumption compared to households in non-MPA villages, after controlling for impact of other factors that determine household consumption. We cannot attribute the lower levels of consumption to the establishment of MPAs, since we do not have baseline data to compare the difference in household consumption levels between MPA villages and non-MPA villages prior to the establishment of MPAs. Other important factors, which were not captured by our survey instrument, may need to be investigated to draw more definitive conclusions regarding the welfare impact of MPAs on coastal communities. 


\section{Appendix}

Table A.1: Summary statistics of variables used in the analysis

\begin{tabular}{lcccc}
\hline \multicolumn{1}{c}{ Variable } & Mean & $\begin{array}{c}\text { Standard } \\
\text { Error }\end{array}$ & Min & Max \\
\hline Use destructive fishing gear & 0.24 & 0.04 & 0 & 1 \\
Own destructive fishing gear & 0.16 & 0.03 & 0 & 1 \\
Fish pelagic species & 0.21 & 0.03 & 0 & 1 \\
Fish reef species & 0.34 & 0.05 & 0 & 1 \\
Rent fishing gear & 0.12 & 0.03 & 0 & 1 \\
Fishing primary activity & 0.32 & 0.04 & 0 & 1 \\
Number of income sources & 2.44 & 0.21 & 0 & 10 \\
Food secure & 0.80 & 0.03 & 0 & 1 \\
Household size & 5.89 & 0.31 & 1 & 11 \\
Female head of household & 0.10 & 0.02 & 0 & 1 \\
Mean male education (years) & 5.53 & 0.47 & 0 & 18 \\
Mean female education (years) & 4.69 & 0.39 & 0 & 15 \\
Own land & 0.70 & 0.06 & 0 & 1 \\
Land area cultivated (acres) & 2.18 & 0.32 & 0 & 40 \\
Access to credit & 0.22 & 0.06 & 0 & 1 \\
Value of physical assets (Tsh) & 324,464 & 29,702 & 0 & $1.09 \mathrm{e}$ \\
MPA village & 0.67 & 0.12 & 0 & 1 \\
Participates in AIGA & 0.11 & 0.03 & 0 & 1 \\
Involved in MPA affairs & 0.29 & 0.05 & 0 & 1 \\
Distance to nearest market (km) & 1.18 & 0.51 & 0 & 5 \\
\hline
\end{tabular}


Table A2: The impact of fishing gear ownership on destructive fishing gear use

\begin{tabular}{|c|c|c|c|c|c|c|}
\hline \multirow[b]{2}{*}{$\begin{array}{c}\text { Independent } \\
\text { Variables }\end{array}$} & \multicolumn{2}{|c|}{$\begin{array}{l}\text { Use Destructive } \\
\text { Fishing Gear (I) }\end{array}$} & \multicolumn{2}{|c|}{$\begin{array}{l}\text { Use Destructive } \\
\text { Fishing Gear (II) }\end{array}$} & \multicolumn{2}{|c|}{$\begin{array}{l}\text { Use Destructive } \\
\text { Fishing Gear } \\
\text { (IV Probit Model) }\end{array}$} \\
\hline & Coefficients & $\begin{array}{r}\text { Standard } \\
\text { Errors } \\
\end{array}$ & Coefficients & $\begin{array}{r}\text { Standard } \\
\text { Errors } \\
\end{array}$ & Coefficients & $\begin{array}{r}\text { Standard } \\
\text { Errors } \\
\end{array}$ \\
\hline Own destructive fishing gear & & & $4.651 * * *$ & 0.599 & $4.484 * * *$ & 0.535 \\
\hline Rent fishing gear & $1.274 * * *$ & 0.196 & $3.377 * * *$ & 0.520 & $1.727 * * *$ & 0.232 \\
\hline Large boat/dhow & $0.964 * * *$ & 0.270 & 0.999 & 0.757 & 0.515 & 0.320 \\
\hline Outrigger or dugout canoe & $1.010 * * *$ & 0.166 & $1.070 * * *$ & 0.230 & $0.567 * * *$ & 0.192 \\
\hline Fishing primary activity & $0.602 * * *$ & 0.214 & 0.017 & 0.233 & 0.174 & 0.244 \\
\hline Food secure & $-0.437 * * *$ & 0.169 & -0.175 & 0.222 & $-0.404 * *$ & 0.211 \\
\hline Household size & $0.084 * * *$ & 0.018 & 0.007 & 0.044 & $0.074 * *$ & 0.028 \\
\hline Female head of household & $0.671 * * *$ & 0.200 & 0.445 & 0.350 & $0.883 * * *$ & 0.228 \\
\hline Mean male education & -0.039 & 0.027 & -0.086 & 0.062 & $-0.073 * *$ & 0.037 \\
\hline Mean female education & 0.022 & 0.019 & 0.068 & 0.043 & 0.042 & 0.029 \\
\hline Own land & -0.017 & 0.238 & -0.422 & 0.341 & -0.231 & 0.276 \\
\hline Land area cultivated & 0.013 & 0.027 & -0.024 & 0.040 & -0.002 & 0.026 \\
\hline Access to credit & $0.379 * *$ & 0.164 & $0.335^{*}$ & 0.184 & $0.465 * *$ & 0.229 \\
\hline Value of physical assets & $-9.80 \mathrm{e}^{-08}$ & $1.75 \mathrm{e}^{-07}$ & $-3.38 \mathrm{e}^{-07}$ & $2.19 \mathrm{e}^{-07}$ & $-3.04 \mathrm{e}^{-07 * *}$ & $1.77 \mathrm{e}^{-07}$ \\
\hline Participates in village meetings & 0.053 & 0.053 & 0.048 & 0.089 & 0.098 & 0.064 \\
\hline Participates in AIGA & $-0.385^{*}$ & 0.227 & $-1.117 * *$ & 0.538 & $-0.993 * * *$ & 0.330 \\
\hline Aware of MPA affairs & 0.194 & 0.179 & -0.241 & 0.286 & -0.054 & 0.213 \\
\hline MPA village & -0.456 & 0.455 & -0.319 & 0.377 & 0.189 & 0.201 \\
\hline Observations & 655 & & 655 & & 655 & \\
\hline Log pseudo-likelihood & -242.79 & & -68.38 & & -151.58 & \\
\hline $\begin{array}{l}\text { Notes: } * * *, * *, * \text { indicate signif } \\
\text { Robust standard errors reported, } \\
\text { Coefficient for dummy variables }\end{array}$ & $\begin{array}{l}\text { ce at the } 99, \\
\text { sted for clust } \\
\text { each of the } \mathrm{M}\end{array}$ & $\begin{array}{l}\text { and } 90 \text { per } \\
\text { ig effect } \\
\text { s and con }\end{array}$ & $\begin{array}{l}\text { confidence } \mathrm{i} \\
\text { not reported }\end{array}$ & al, res & & \\
\hline
\end{tabular}

When we omit the ownership of fishing gear from the analysis (column I), the results suggest that fishing related factors, as well as some household characteristics, are important determinants of the use of destructive fishing gear. In particular, households primarily dependent on fishing for income generation are significantly more likely to use destructive fishing gear. Ownership of any type of fishing gear is likely to be correlated with the use of other fishing inputs, such as boats and canoes. Households that dependent mostly on fishing may also be the ones more likely to own fishing gear. Once we control for ownership of destructive fishing gear, households dependent on fishing are not significantly more likely to use destructive fishing gear. Not surprisingly, the large coefficient on the ownership variable does suggest that if households own such destructive gear, they are very likely to use it. This suggests that failing to account for the impact of ownership generates biased coefficients in the simple probit model 


\section{References}

Berachi, I., 2003. Bioeconomic "Analysis of Artisanal Marine Fisheries of Mainland Tanzania." Norwegian College of Fishery Science, University of Tromso, Norway.

Bardhan, P., and C. Udry. 1999. Development Microeconomics. Oxford: Oxford University Press.

Brandon, K., K. Redford, and S. Sanderson (eds.). 1998. Parks in Peril: People, Politics, and Protected Areas. Washington DC: Island Press.

Botsford, L. 2005. "Potential Contribution of Marine Reserves to Sustainable Fisheries: Recent Modeling Results.” Bulletin of Marine Science, 76, pp. 245-260.

Botsford, L., F. Micheli, and A. Hastings. 2003. "Principles for the Design of Marine Reserves." Ecological Applications, 13, Supplement, pp. S25-S31.

Carter, D. 2003. "Protected Areas in Marine Resource Management: Another Look at the Economics and Research Issues." Ocean and Coastal Management, 46, pp. 439-456.

Collier P., S. Radwan, and S. Wangwe, and A. Wagner. 1990. Labour and Poverty in Rural Tanzania: Ujamaa and Rural Development in the United Republic of Tanzania. Oxford: Clarendon Press.

Deaton, A. 1997. The Analysis of Household Surveys: A Microeconometric Approach to Development Policy. Baltimore, MD: John Hopkins University Press.

Food and Agriculture Organization (FAO). 2000. "Poverty in Coastal Fishing Communities." Report of the Third Session of the Advisory Committee on Fisheries Research. Rome 5-8 December 2000.

Greene, W. 1997. Econometric Analysis. New Jersey: Prentice-Hall.

Hannesson, R. 2002. "The Economics of Marine Reserves.” Natural Resources Modeling, 15, pp. 273-290.

Hastings, A., and L. Botsford. 2003. "Comparing Designs of Marine Reserves for Fisheries and for Biodiversity.” Ecological Applications, 13, pp. S65-S70.

Heady, C. 2000. "Natural Resource Sustainability and Poverty Reduction," Environment and Development Economics, 5, pp. 241-258.

Hilborn, R., D. Stokes, J. Maguire, T. Smith, L. Botsford, M. Mangel, J. Orensanz, A. Parma, J. Rice, J. Bell, K Cochrane, S. Garcia, S. Hall, G. Kirkwood, K Sainsbury, G. Stefansson, and C. Walters. 2004. "When Can Marine Reserves Improve Fisheries Management?" Ocean and Coastal Management, 47, pp. 197-205.

Ireland, C. 2004. "Alternative Sustainable Livelihoods for Coastal Communities-A Review of Experience and Guide to Best Practice. Report prepared by the IDLgroup for IUCN.

Kazimoto, M. 2005. "Marine Protected Area Management for Sustainable Resource UseExperience from Mafia Marine Island Park.” Paper presented at the Marine and Coastal Conservation and Management Seminar in Dar es Salaam on June 27, 2005.

Kramer, R., C. van Schaik, and J. Johnson. 1997. Lessons from the Field: A Review of World Wildlife Fund's Experience with Integrated Conservation and Development Projects 19851996. New York: Oxford University Press.

Jiddawi, N., and M. Ohman. 2002. "Marine Fisheries in Tanzania.” Ambio, 31, pp. 518-527. 
Leon, Y., J. Tobey, E. Torrel, R. Mwaipopo, A. Mkenda, Z. Ngazy, and F. Mbarak. 2004. "Marine Protected Areas and Poverty Alleviation: An Empirical Study of 24 Coastal Villages on Mainland Tanzania and Zanzibar." In J. Ruitenbeek, I. Hewawasam, and M. Ngoile (eds.), Blue Print 2050: Sustaining the Marine Environment in Mainland Tanzania and Zanzibar. Washington DC: The World Bank.

Maddala, G. 1983. Limited Dependent and Qualitative Variables in Econometrics. Cambridge: Cambridge University Press.

Makoloweka, S. and H. Kalombo. 2005. "Tanga Experience on Marine and Coastal Conservation and Management." Paper presented at the Marine and Coastal Conservation and Management Seminar in Dar es Salaam on June 27, 2005.

Ministry of Agriculture, Natural Resources, Environment, and Cooperatives (MANREC). 2005. Rapid Assessment of the Proposed Pemba Channel Conservation Area. Report prepared by EcoAfrica Environmental Consultants.

Muller, J., S. Bettencourt, and R. Gillett. 2000. "A Comparative Study of Socio-Economic and Management Issues Related to Coastal Resources in the Pacific Islands.” In H. Cesar (ed.), Collected Essays on the Economics of Coral Reefs. Kalmar, Sweden: CORDIO.

Narayan, D. and L. Prichett. 1999. "Cents and Sociability: Household Income and Social Capital in Rural Tanzania." Economic Development and Cultural Change, 47, pp. 871-897.

National Bureau of Statistics Tanzania, 2002. "Household Budget Survey 200/01: Key Findings."

Oates, J. 1999. Myth and Reality in the Rain Forest: How Conservation Strategies are Failing in West Africa. Berkeley, CA: University of California Press.

Pezzey, J., C. Roberts, and B. Urdal. 2000. “A Simple Bioeconomic Model of a Marine Reserve.” Ecological Economics, 33, pp. 77-91.

Pollnac, R., B. Crawford, and M. Gorospe .2001. "Discovering Factors that Influence the Success of Community-based Marine Protected Areas in the Visayas, Philippines," Ocean and Coastal Management, 44, pp. 683-710.

Pomeroy, R., R. Pollnac, B. Katon, and C. Predo. 1997. "Evaluating Factors Contributing to the Success of Community Based Coastal Resource Management: The Central Visayas Regional Project-1, Philippines." Ocean and Coastal Management, 36, pp. 97-120.

Reardon, T. and S. Vosti. 1995. Links Between Rural Poverty and the Environment in Developing Countries: Asset Categories and Investment Poverty. World Development, 23, pp. 1495-1506.

Rumisha, C.K. 2005. “Marine Parks and Reserves Unit's Vision and Next Steps towards a Network for Marine Conservation." Paper presented at the Marine and Coastal Conservation and Management Seminar in Dar es Salaam on June 27, 2005.

Ruitenbeek, J., I. Hewawasam, and M. Ngnoile, (eds.). 2005. Blueprint 2050: Sustaining the Marine Environment in Mainland Tanzania and Zanzibar. Washington DC: The World Bank.

Scientific Consensus Statement on Marine Reserves and Marine Protected Areas. 2001. Santa Barbara, CA: University of California, National Center for Ecological Analysis and Synthesis. 
Singh, I., L. Squire, and J. Strauss. 1986. Agricultural Household Models: Extensions, Applications and Policy. Baltimore, MD: Johns Hopkins University Press.

Silva, P., P. Eliste, A. Mkenda. 2004. Poverty Analysis of Coastal Communities in Tanzania. In J. Ruitenbeek, I. Hewawasam, and M. Ngoile (eds.), Blue Print 2050: Sustaining the Marine Environment in Mainland Tanzania and Zanzibar. Washington DC: The World Bank.

Smith, M., and J. Wilen. 2003. "Economic Impacts of Marine Reserves: the Importance of Spatial Behavior." Journal of Environmental Economics and Management, 46, pp. 183-206.

StataCorp. 2003. Stata Statistical Software: Release 8.0. Reference Manual. College Station, TX: Stata Corporation.

Tanzania Coastal Management Partnership (TCMP). 2005. "Pwani Yetu," TCMP Newsletter Issue no. 25, April-June 2005.

Tanzania Coastal Management Partnership (TCMP). 2003. "Tanzania State of the Coast 2001:

The National ICM Strategy and Prospects for Poverty Reduction,” TCMP Coastal

Management Report \#2002, Dar es Salaam, August 2003. 